\title{
RELATIONSHIP BETWEEN DIGITAL MARKETING CAPABILITY AND CONSUMER BEHAVIOR PURCHASE INTENTION ON DIGITAL PLATFORMS WITH BLOCKCHAIN TECHNOLOGY AS A MODERATING VARIABLE
}

\author{
Yang Wang \\ Panyapiwat Institute of Management, Nonthaburi, Thailand
}

The advancement of global technology affects consumers' purchasing behavior. With the popularization of the Internet and mobile tools, people's shopping methods are gradually shifting from offline to digital online via Internet and mobile communications. These marketplaces have very high requirements in terms of marketing capabilities and mobile communications. Digital marketing capabilities (DMC) have become the core of companies' competitiveness. Blockchain technology $(B T)$ is becoming the latest technology to disrupt this industry after big data. Applying BT to the digital purchase platforms to build effective DMC has become an important part of the core competitiveness of many Internet companies. Constructing a consumer behavior model for DMC with a moderating effect of BT based on the research on consumer behavior intentions on digital platforms (DPCI) has become the key objective of our study. Interviews and questionnaire surveys have been mainly conducted with digital platform managers as the key research object. SPSS has been used on the 300 valid questionnaires received. We may conclude that DMC positively affects DPCI, and BT is playing a regulatory role on both of them. Our empirical results enrich the theoretical model of DMC.

Keywords: digital marketing; trust; safety; regulatory environment; digital platforms; consumer behavior intentions

\section{Introduction}

DMC is a combination of targeted marketing, direct marketing, decentralized marketing, customer-oriented marketing, dual interactive marketing, remote or global marketing, virtual marketing, paperless transactions, and direct marketing.

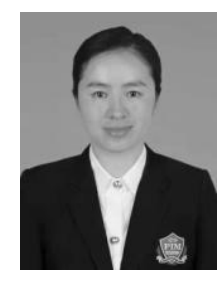

\section{Yang Wang}

PhD Student, Chinese Graduate School, Panyapiwat Institute of Management, Nonthaburi, Thailand. Research Interests: Digital economy, Digital marketing 


\section{RELATIONSHIP BETWEEN DIGITAL MARKETING}

Today, digital platforms have become an everyday phenomenon already. They change the models of the goods and services markets as well as relations within the supply chains and with manufacturers. The market boundaries are becoming more blurred, and this has already affected customers (Evans, 2016). Nowadays, technologies such as big data, artificial intelligence (AI), cloud computing, Internet of Things (IOT), quantum computing, and BT have become important goals of the national strategic development policies, as this is the way how all countries may achieve economic modernization.

There are nearly $30 \mathrm{mln}$ SMEs (small and medium-sized enterprises) in China these days, and more than $90 \%$ of them need to transform their marketing methods. Based on the above information, DMC can solve the following four major problems:

1. The problem of asymmetry in information communication between enterprises and consumers.

2. The problem of weak anti-counterfeiting methods applied today.

3. The problem of inefficient sales promotion.

4. The problem of low advertising efficiency.

This article takes digital platform managers as the research objects and BT as a moderator for studying the influence of DMC and DPCI. Our research tasks are as follows:

1. To reveal the mechanism behind the effect of DMC on DPCI, and more fully, to reflect the relationship between DMC and BT;

2. To optimize the management system through the integration of DMC and BT to influence DPCI, and work together to maximize their effectiveness, increase DPCI, to provide a new perspective on DMC.

The expected research results would have several levels of significance.

1. Practical significance: much better understanding of what digital economy is, and how core competencies of companies can be built on it.

2. Methodological significance. This study is using quantitative research methods to explore the mechanism behind the relationship between DMC and DPCI in the Chinese context and it is also using models and research methods to analyze and measure the effects of DMC on DPCI.

3. Theoretical significance. This study uses the stakeholder theory and the relationship marketing theory to conduct empirical research on the relationship between DMC and DPCI for the first time in China (to the best of our knowledge) and to introduce BT as a moderating variable affecting both DMC and DPCI, thus making the research system richer and more comprehensive.

\section{Literature review}

\section{Digital marketing capability (DMC)}

According to Day (2011), DMC is the ability of a company to use digital resources to perform a set of coordinated digital-related tasks to achieve competitive advantage. Taiminen, H. \& Karjaluoto, H. (2015) refer to DMC as to the relationship capabilities required to take advantage of digital advantages. DMC and the related functions enable companies to adjust their resource allocation and develop new skills to handle real-time connectivity between stakeholders (Kane et al., 2015).

DMC must be inherently dynamic in order to make responsive and flexible decisions (Teece \& Feiler, 2014). Mathews et al. (2016) stated that digital marketing focuses on the 
influence of customers, market activities, and Internet marketing functions. Although organizations see digitalization as the main trend these days, they still lag behind consumers when it comes to digital adoption rates.

Fatima (2020) has found that company size and entrepreneurial direction have a moderating effect on DMC and company performance. This author has provided empirical evidence on the performance results of DMC, comparing the impact of DMC on large, medium, and small enterprises. Generally speaking, DMC has responded to the acute practical call to narrow the marketing capability gap between the available resources and the required resources to cope with the complexity and speed of the digital market (Day, 2011).

In the light of the literature above, this article defines DMC as a dynamic relationship function. Referring to (Fatima, 2020), scale indicators may be used to analyze the specific content of DMC: creating and managing lasting customer relationships through digital media, using digital media to predict changes in customer preferences and also using digital marketing to meet customer needs and achieve the ability to retain customers. This leads us to formulation of the following hypotheses:

Hypothesis H1: DMC is positively correlated with DPCI.

Hypothesis H1a: Creating and managing lasting customer relationships is positively correlated with DPCI.

Hypothesis H1b: Predicting changes in customer preferences is positively correlated with DPCI.

Hypothesis H1c: The ability to use digital marketing to meet customer needs and thus achieve customer retention is positively correlated with DPCI.

\section{Blockchain technology $(B T)$}

BT is based on cryptography, a way of writing and solving codes to safely convey messages (Diffie \& Hellman, 1976). Blockchain originally started with distributed ledger technology (DLT) as the basis for bitcoin and other cryptocurrencies (Nakamoto, 2008). It can be used anywhere as a digital, trustworthy, decentralized ledger and it may also have other functions, which is why it is used as a distributed tool by companies in various business fields in a consensus manner (Antonopoulos, 2017).

Blockchain is a kind of digital ledger or a database that can keep all unchanging operating records and transaction content (Drescher, 2017). When applied to business, the benefits of blockchain include cost saving, time saving, simplified procedures, enhanced customer trust system, higher security, higher transparency, less tampering and fraud, and reduced auditing requirements. Thus, BT is known to be reducing overhead and human errors caused by manual processes, it is also reducing transaction costs, etc. (de Oliveira, 2017).

This paper refers to (Treiblemaier, 2019; Clohessy et al., 2019), as both these studies are suitable for the topic of this paper. Security and trust in the case with blockchain are formed by the five characteristics of anonymity, traceability, transparency, smart contract, and distributed accounting. Developed in 2019, the BT scale is composed of the three dimensions of the regulatory environment and can be used as the main reference scale.

\section{Stakeholders}

Penrose (1959) wrote that "a company is a collection of human assets and interpersonal relationships", thus laying the foundation for the composition of stakeholders". The pioneer of stakeholder theory, Gwin (1990) was the first scholar who proposed applying stakeholder 


\section{RELATIONSHIP BETWEEN DIGITAL MARKETING}

theory to relationship marketing. This article is based on the previous studies, as through indepth analysis of DPCI it attempts to understand the importance of today's consumer behavior intentions when it comes to expanding DMC. It also strives to establish a digital marketing strategy system based on the stakeholder theory to overcome the strategic limitations of the existing marketing theories.

\section{Relationship marketing theory}

Relationship marketing is an interactive process between an organization and the related stakeholders (such as consumers, suppliers, agents, competitors, etc.) which is based on a solid but constantly developing foundation. (Rowley et al., 1997) have put forward the view that any market is composed of transaction networks. Relationship marketing theory also examines the existence of these subsystems (Gronroos, 1994), thus expanding the relationship marketing based on stakeholder groups. Dwyer (1987) pointed out that stakeholder theory and relationship marketing theory have a lot of differences and are inextricably linked. Svendsen pointed out that organizations must first of all respond to the needs of stakeholders (Svendsen, 1998).

Based on the above literature, this article will be studying the relationship between DMC and DPCI which is regarded to be a positive correlation, and the most suitable scale for our purposes seems to be the one suggested by Herhausen et al. (2020). This scale has the total nine dimensions of purchase intentions as the measurement indicators. This leads to formulating the following hypotheses:

Hypothesis H2: BT has a positive regulatory effect on DMC and DPCI.

Hypothesis H2a: BT security has a positive regulatory effect on DMC and DPCI.

Hypothesis H2b: BT trust has a positive regulatory effect on DMC and DPCI.

Hypothesis H2c: BT environmental supervision has a positive regulatory effect on DMC and DPCI.

Table 1 - Summary of the author's models

(made by the author)

\begin{tabular}{|c|l|}
\hline H1 & DMC is positively correlated with DPCI \\
\hline H1a & Creating and managing lasting customer relationships is positively correlated with DPCI \\
\hline H1b & Predicted changes in customer preferences are positively correlated with DPCI \\
\hline H1c & $\begin{array}{l}\text { The ability to use digital marketing to meet customer needs and thus achieve customer } \\
\text { retention is positively correlated with DPCI }\end{array}$ \\
\hline H2 & BT has a positive regulatory effect on DMC and DPCI \\
\hline H2a & BT security has a positive regulatory effect on DMC and DPCI \\
\hline $\begin{array}{c}\text { H2b } \\
:\end{array}$ & BT trust has a positive regulatory effect on DMC and DPCI \\
\hline H2c & BT environmental supervision has a positive regulatory effect on DMC and DPCI \\
\hline
\end{tabular}

From the above, a hypothetical model of DPCI for DMC has been constructed by the author and is shown in the figure below. 


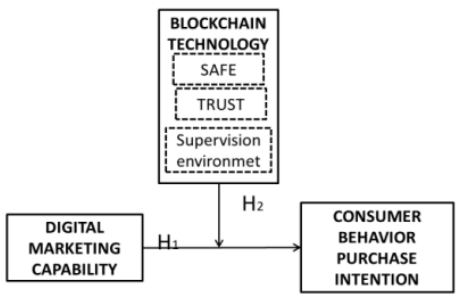

Figure 1 - Hypothetical Model of DPCI of DMC

(made by the author)

\section{Research methods}

1. Interview method: This article uses the interview method to conduct on-site interviews with the digital platforms managers. The interviewees we've managed to reach out to have been either digital platform managers, or business owners. The total of eight people were interviewed.

2. Questionnaire survey method: In order to understand the reasons that affect the performance of digital marketing platforms, we have also conducted a survey of the people who are directly involved in promotion and/or management of digital platforms.

Due to the epidemic, the number of questionnaires received did not reach the expected number (set initially at 400). However, as the questionnaires were mainly filled out by the people at the supervisor level or above, we have all reasons to believe that they do reflect the currently existing problems in the studied field. The questionnaire has adopted a Likert scale.

Collecting questionnaires and then conducting SPSS analysis on them, we have found that DMC positively affects DPCI, while BT plays a positive role in regulating DMC and DPCI. Thus, our empirical data enriches our initial theoretical assumptions.

\section{Results and discussion}

Summary of questionnaires collection.

Table 2 - Valid questionnaires

(made by the author)

\begin{tabular}{|l|l|c|c|}
\hline \multicolumn{2}{|c|}{} & $\mathrm{N}$ & $\%$ \\
\hline \multirow{2}{*}{$\begin{array}{l}\text { Valid } \\
\text { questionna } \\
\text { ires }\end{array}$} & All questionnaires & 309 & 100.0 \\
\cline { 2 - 4 } & Weeded out & 9 & $2.9 \%$ \\
\cline { 2 - 4 } & Effective & 300 & $97 \%$ \\
\cline { 2 - 4 } & Total & 300 & 100.0 \\
\hline
\end{tabular}

Among the 309 questionnaires retrieved, four turned out to be having duplicated numbers and five were assumed as invalid. 


\section{RELATIONSHIP BETWEEN DIGITAL MARKETING}

Table 3 - Reliability analysis results

(made by the author)

\begin{tabular}{|c|c|c|c|c|c|}
\hline Item & Subitems under inspection & $\frac{0}{0}$ & 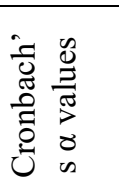 & 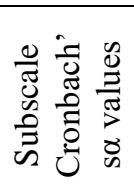 & 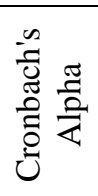 \\
\hline \multirow[t]{3}{*}{ DMC } & $\begin{array}{l}\text { Creating and managing lasting customer relationships } \\
\text { through digital media }\end{array}$ & $\mathrm{DMC}_{1}$ & 0.743 & \multirow[t]{3}{*}{0.837} & \multirow[t]{17}{*}{0.933} \\
\hline & $\begin{array}{l}\text { Using digital media to predict changes in customer } \\
\text { preferences }\end{array}$ & $\mathrm{DMC}_{2}$ & 0.742 & & \\
\hline & The ability to use digital marketing to retain customers & $\mathrm{DMC}_{3}$ & 0.834 & & \\
\hline \multirow[t]{9}{*}{ DPCI } & $\begin{array}{l}\text { Platform interactive services enable consumers to } \\
\text { reach purchase intentions }\end{array}$ & $\mathrm{DPCI}_{1}$ & 0.947 & \multirow[t]{9}{*}{0.951} & \\
\hline & $\begin{array}{l}\text { The response speed of the platform enables consumers } \\
\text { to reach purchase intentions }\end{array}$ & $\mathrm{DPCI}_{2}$ & 0.944 & & \\
\hline & $\begin{array}{l}\text { The ease of use of platform services enables } \\
\text { consumers to reach purchase intentions }\end{array}$ & $\mathrm{DPCI}_{3}$ & 0.943 & & \\
\hline & $\begin{array}{l}\text { The quality of platform information enables } \\
\text { consumers to reach purchase intentions }\end{array}$ & $\mathrm{DPCI}_{4}$ & 0.945 & & \\
\hline & $\begin{array}{l}\text { Platform service trust allows consumers to reach } \\
\text { purchase intentions }\end{array}$ & $\mathrm{DPCI}_{5}$ & 0.945 & & \\
\hline & $\begin{array}{l}\text { Platform design enables consumers to reach purchase } \\
\text { intentions }\end{array}$ & $\mathrm{DPCI}_{6}$ & 0.947 & & \\
\hline & $\begin{array}{l}\text { Platform service security enables consumers to reach } \\
\text { purchase intentions }\end{array}$ & $\mathrm{DPCI}_{7}$ & 0.944 & & \\
\hline & $\begin{array}{l}\text { Platform services and product quality enable } \\
\text { consumers to reach purchase intentions }\end{array}$ & $\mathrm{DPCI}_{8}$ & 0.946 & & \\
\hline & $\begin{array}{l}\text { Platform responsibility enables consumers to reach } \\
\text { purchase intentions }\end{array}$ & $\mathrm{DPCI}_{9}$ & 0.945 & & \\
\hline \multirow[t]{5}{*}{ BT } & $\begin{array}{l}\text { Set access permissions for pre-defined customers, } \\
\text { increase the customer's sense of security, and make } \\
\text { customers generate purchase intentions }\end{array}$ & $\mathrm{BT}_{1 \mathrm{a}}$ & .974 & \multirow[t]{5}{*}{0.921} & \\
\hline & $\begin{array}{l}\text { The non-falsification of the transaction increases the } \\
\text { customer's sense of security and the customer has the } \\
\text { intention to buy }\end{array}$ & $\mathrm{BT}_{1 \mathrm{~b}}$ & .973 & & \\
\hline & $\begin{array}{l}\text { Transparency of information communication and } \\
\text { transactions promotes the reading of buyers and } \\
\text { sellers, makes customers feel safe and makes } \\
\text { customers feel more willing to buy }\end{array}$ & $\mathrm{BT}_{1 \mathrm{c}}$ & .974 & & \\
\hline & $\begin{array}{l}\text { The complexity of the script used by the network } \\
\text { currency is difficult to imitate, and high efficiency of } \\
\text { the smart contract increases the customer's sense of } \\
\text { security and makes the customer generate purchase } \\
\text { intentions }\end{array}$ & $\mathrm{BT}_{1 \mathrm{~d}}$ & .973 & & \\
\hline & $\begin{array}{l}\text { The distributed ledgers kept by all parties to the } \\
\text { transaction are embedded in the ever-growing record } \\
\text { blocks, which are controlled by passwords and } \\
\text { distributed consensus mechanisms, increase the sense } \\
\text { of security among customers and make them generate } \\
\text { purchase intentions }\end{array}$ & $\mathrm{BT}_{1 \mathrm{e}}$ & .974 & & \\
\hline
\end{tabular}




\begin{tabular}{|c|c|c|c|}
\hline $\begin{array}{l}\text { Set access permissions for pre-defined customers to } \\
\text { increase customer trust and make customers generate } \\
\text { purchase intentions }\end{array}$ & $\mathrm{BT}_{2 \mathrm{a}}$ & .973 & \multirow[t]{5}{*}{0.933} \\
\hline $\begin{array}{l}\text { The non-falsification of the transaction increases the } \\
\text { trust of the customer and the customer has the } \\
\text { intention to buy }\end{array}$ & $\mathrm{BT}_{2 \mathrm{~b}}$ & .973 & \\
\hline $\begin{array}{l}\text { Transparency of information communication and } \\
\text { transactions promotes the reading of buyers and } \\
\text { sellers, creates trust in customers, and the willingness } \\
\text { to buy }\end{array}$ & $\mathrm{BT}_{2 \mathrm{c}}$ & .973 & \\
\hline $\begin{array}{l}\text { Complexity of the script used by the network currency } \\
\text { is difficult to imitate, and efficiency of the smart } \\
\text { contract increases the trust among customers and } \\
\text { generates purchase intentions }\end{array}$ & $\mathrm{BT}_{2 \mathrm{~d}}$ & .973 & \\
\hline $\begin{array}{l}\text { The distributed ledgers kept by all parties to the } \\
\text { transaction are embedded in the ever-growing record } \\
\text { blocks which are controlled by passwords and } \\
\text { distributed consensus mechanisms to increase } \\
\text { customer trust and make customers generate more } \\
\text { purchase intentions }\end{array}$ & $\mathrm{BT}_{2 \mathrm{e}}$ & .974 & \\
\hline $\begin{array}{l}\text { Setting access permissions for pre-defined customers } \\
\text { can strengthen the platform supervision environment } \\
\text { and make customers generate more purchase } \\
\text { intentions }\end{array}$ & $\mathrm{BT}_{3 \mathrm{a}}$ & .973 & \multirow[t]{5}{*}{0.922} \\
\hline $\begin{array}{l}\text { The transactions cannot be tampered with, thus } \\
\text { strengthening the platform supervision environment, } \\
\text { and making customers generate more purchase } \\
\text { intentions }\end{array}$ & $\mathrm{BT}_{3 \mathrm{~b}}$ & .973 & \\
\hline $\begin{array}{l}\text { Transparency of information communication and } \\
\text { transactions promotes the reading of buyers and } \\
\text { sellers, makes customers feel more safe, strengthens } \\
\text { the supervision environment of the platform, thus } \\
\text { making customers want to buy more }\end{array}$ & $\mathrm{BT}_{3 \mathrm{c}}$ & .973 & \\
\hline $\begin{array}{l}\text { Complexity of the script used by the network currency } \\
\text { is difficult to imitate, while high efficiency of smart } \\
\text { contracts enhances the platform supervision } \\
\text { environment and makes customers generate more } \\
\text { purchase intentions }\end{array}$ & $\mathrm{BT}_{3 \mathrm{~d}}$ & .974 & \\
\hline $\begin{array}{l}\text { The distributed ledgers kept by all parties to the } \\
\text { transaction are embedded in the ever-growing record } \\
\text { blocks, which are controlled by passwords and } \\
\text { distributed consensus mechanisms. The enhanced } \\
\text { platform supervision environment enables customers' } \\
\text { purchase intentions. }\end{array}$ & $\mathrm{BT}_{3 \mathrm{e}}$ & .975 & \\
\hline
\end{tabular}

Thus, the total of nine questionnaires was disregarded from the sample to be taken for further analysis.

\section{Reliability and validity analysis}

These two are the indicators that reflect the consistency and/or stability of the measurement results. The higher the reliability of the measurement, the more credible the measurement result is. 


\section{RELATIONSHIP BETWEEN DIGITAL MARKETING}

In order to make the results more convincing, this article has carried out specific tests on each dimension of the measurement The above shows that the test results are all above 0.74 , thus indicating that the data in this questionnaire has a very high credibility level.

Validity analysis

Table 4 - Validity analysis

(made by the author)

\begin{tabular}{|l|c|c|c|c|c|}
\hline \multirow{2}{*}{\multicolumn{1}{|c|}{ Items }} & Codes & Adequate sampling & \multicolumn{2}{c|}{ Bartlett sphericity test } \\
\cline { 3 - 7 } & & $\begin{array}{c}\text { Kaiser-Meyer- } \\
\text { OlkinMeasure }\end{array}$ & $\begin{array}{c}\text { Approximate } \\
\text { chi-square }\end{array}$ & df & Sig. \\
\hline Digital Marketing Capability & DMC & .710 & 368.119 & 3 & .000 \\
\hline $\begin{array}{l}\text { Digital Platform Consumer } \\
\text { Purchasing Intention }\end{array}$ & DPCI & .947 & 2333.590 & 36 & .000 \\
\hline Blockchain Technology & BT & .965 & 5149.877 & 105 & .000 \\
\hline
\end{tabular}

The value of KMO is between $0-1$. What is also examined here is the partial correlation between the variables in question. The KMO value of DMC is 0.71 , and for DPCI it is 0.947 . There is a significant difference in the unit matrix, the correlation of the internal variables is relatively large, and the detection result is very good. The BT detection result is 0.965 , as shown in Table 4 above. This value is significant. The measurement results are very good and suitable for factor analysis.

\section{Descriptive analysis}

Descriptive statistical analysis of the sample data through such indicators as maximum value, minimum value, mean, variance, standard deviation, skewness and kurtosis, analyze the distribution patterns and the characteristics of the sample data, thus testing whether the sample data meets the research hypothesis logic.

From the results of the descriptive statistical analysis of the characteristics of the sample data in Tab. 5, the average value of each item is between 3.87-4.1667, which shows that the distribution is relatively balanced.

The standard deviation of each item is between $0.849-0.98372$, thus indicating that the sample data dispersion is small. Klein (1998) believed that when the absolute value of the sample data skewness is less than 3 and the absolute value of kurtosis is less than 8 , it can be considered that the observed variable basically conforms to the normal distribution. From the above statistical results, the absolute value of skewness of all the items is $\leq 1.158$, and the absolute value of kurtosis is $\leq 1.733$, which is much smaller than the reference value proposed in (Klein, 1998). Therefore, it can be considered that the sample data basically conforms to the normal distribution and meets the basic requirements of the research hypothesis for the analysis of data in this paper.

In the dimension of DMC, it is 3.87 to 3.95 , and the standard deviation is between 0.952 and 0.984 , thus indicating that digital marketing platform managers generally believe that DMC can increase DPCI. In the dimensions of DPCI, the mean value is within the range of 3.96-4.17, and the standard deviation is within 0.849-0.909, thus indicating that these 
behaviors of digital platform consumers can indeed increase consumption by improving the status of digital platforms. The average value of the BT dimension is within 3.87-4.02, and the standard deviation is $0.865-0.957$, thus indicating that DMC can enhance DPCI through BT.

Table 5 - Descriptive Analysis $(\mathrm{N}=300)$

(made by the author)

\begin{tabular}{|c|c|c|c|c|c|c|c|c|}
\hline & \multicolumn{8}{|c|}{ Descriptive statistics } \\
\hline & \multirow{2}{*}{ 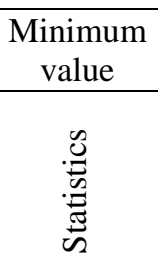 } & \multirow{2}{*}{ 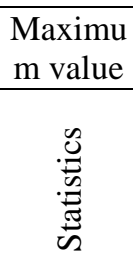 } & \multirow{2}{*}{ 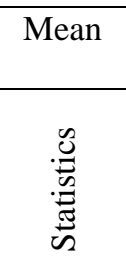 } & \multirow{2}{*}{ 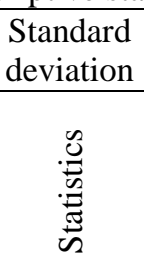 } & \multicolumn{2}{|c|}{ Skewness } & \multicolumn{2}{|c|}{ Kurtosis } \\
\hline & & & & & 菢 & 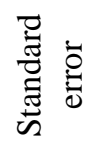 & 苛 & 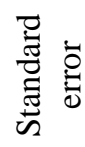 \\
\hline $\mathrm{DMC}_{1}$ & 1.00 & 5.00 & 3.8833 & .95188 & -.631 & .141 & .051 & .281 \\
\hline $\mathrm{DMC}_{2}$ & 1.00 & 5.00 & 3.9533 & .98372 & -1.158 & .141 & 1.332 & .281 \\
\hline $\mathrm{DMC}_{3}$ & 1.00 & 5.00 & 3.8667 & .97916 & -.741 & .141 & .248 & .281 \\
\hline $\mathrm{DPCI}_{1}$ & 1.00 & 5.00 & 3.9600 & .84900 & -.716 & .141 & .602 & .281 \\
\hline $\mathrm{DPCI}_{2}$ & 1.00 & 5.00 & 4.0300 & .86695 & -.957 & .141 & 1.138 & .281 \\
\hline $\mathrm{DPCI}_{3}$ & 1.00 & 5.00 & 4.0333 & .86102 & -.824 & .141 & .703 & .281 \\
\hline $\mathrm{DPCI}_{4}$ & 1.00 & 5.00 & 4.0700 & .89504 & -1.011 & .141 & 1.023 & .281 \\
\hline $\mathrm{DPCI}_{5}$ & 1.00 & 5.00 & 4.1200 & .86878 & -1.128 & .141 & 1.521 & .281 \\
\hline $\mathrm{DPCI}_{6}$ & 1.00 & 5.00 & 3.9767 & .88623 & -.854 & .141 & .896 & .281 \\
\hline $\mathrm{DPCI}_{7}$ & 1.00 & 5.00 & 4.0867 & .89918 & -1.005 & .141 & 1.085 & .281 \\
\hline $\mathrm{DPCI}_{8}$ & 1.00 & 5.00 & 4.1667 & .87260 & -1.182 & .141 & 1.733 & .281 \\
\hline $\mathrm{DPCI}_{9}$ & 1.00 & 5.00 & 4.0233 & .90859 & -.962 & .141 & .946 & .281 \\
\hline $\mathrm{BLCH}_{1 \mathrm{a}}$ & 1.00 & 5.00 & 3.8900 & .91690 & -.724 & .141 & .657 & .281 \\
\hline $\mathrm{BLCH}_{1 \mathrm{~b}}$ & 1.00 & 5.00 & 3.9700 & .90840 & -.830 & .141 & .796 & .281 \\
\hline $\mathrm{BLCH}_{1 \mathrm{c}}$ & 1.00 & 5.00 & 3.9933 & .92166 & -.864 & .141 & .756 & .281 \\
\hline $\mathrm{BLCH}_{1 \mathrm{~d}}$ & 1.00 & 5.00 & 3.9967 & .93070 & -.971 & .141 & 1.026 & .281 \\
\hline $\mathrm{BLCH}_{1 \mathrm{e}}$ & 1.00 & 5.00 & 3.9933 & .91437 & -.832 & .141 & .625 & .281 \\
\hline $\mathrm{BLCH}_{2 \mathrm{a}}$ & 1.00 & 5.00 & 3.8700 & .96759 & -.629 & .141 & .149 & .281 \\
\hline $\mathrm{BLCH}_{2 \mathrm{~b}}$ & 1.00 & 5.00 & 4.0133 & .89582 & -.841 & .141 & .898 & .281 \\
\hline $\mathrm{BLCH}_{2 \mathrm{c}}$ & 1.00 & 5.00 & 3.9700 & .93381 & -.957 & .141 & 1.079 & .281 \\
\hline $\mathrm{BLCH}_{2 \mathrm{~d}}$ & 1.00 & 5.00 & 4.0300 & .93022 & -1.089 & .141 & 1.403 & .281 \\
\hline $\mathrm{BLCH}_{2 \mathrm{e}}$ & 1.00 & 5.00 & 3.9800 & .90683 & -.800 & .141 & .619 & .281 \\
\hline $\mathrm{BLCH}_{3 \mathrm{a}}$ & 1.00 & 5.00 & 3.9733 & .95691 & -.938 & .141 & .855 & .281 \\
\hline $\mathrm{BLCH}_{3 \mathrm{~b}}$ & 1.00 & 5.00 & 3.9933 & .92528 & -.879 & .141 & .873 & .281 \\
\hline $\mathrm{BLCH}_{3 \mathrm{c}}$ & 1.00 & 5.00 & 3.9933 & .86552 & -.891 & .141 & 1.295 & .281 \\
\hline $\mathrm{BLCH}_{3 \mathrm{~d}}$ & 1.00 & 5.00 & 4.0267 & .88046 & -.792 & .141 & .627 & .281 \\
\hline $\mathrm{BLCH}_{3 \mathrm{e}}$ & 1.00 & 5.00 & 3.9467 & .93456 & -.760 & .141 & .469 & .281 \\
\hline
\end{tabular}

\section{Regulation detection}

According to Herhausenб D. et al. (2020) results concerning the moderating effect test, if the regression coefficient is significant, the moderating effect is proved.

M1 is the regression of the dependent variable DPCI on the control variable; M2 is the regression of adding the modulating variable BT and the independent variable; $\mathrm{M} 3$ is the regression of adding the independent variable levels and the interaction terms of the modulating variable. The running results are shown in Tab. 6. 


\section{RELATIONSHIP BETWEEN DIGITAL MARKETING}

Table 6 - Moderating variable test

(made by the author)

\begin{tabular}{|c|c|c|c|c|c|c|c|}
\hline \multicolumn{4}{|c|}{ General hypothesis adjustment test } & \multicolumn{4}{|c|}{ Sub-hypothesis adjustment test } \\
\hline \multirow[t]{2}{*}{ Item } & \multicolumn{3}{|c|}{ Dependent variable: DPCI } & \multirow[t]{2}{*}{ Item } & \multicolumn{3}{|c|}{ Dependent variable: DPCI } \\
\hline & M1 & M2 & M3 & & M1 & M2 & M3 \\
\hline \multicolumn{8}{|c|}{ Control variable } \\
\hline GENDER & -.050 & $-.034^{b}$ & $-.030^{b}$ & GENDER & -.035 & $-.028^{b}$ & $-.021^{b}$ \\
\hline AGE & .089 & $.060^{\mathrm{b}}$ & $.061^{\mathrm{b}}$ & AGE & .091 & $.068^{\mathrm{b}}$ & $.072^{\mathrm{b}}$ \\
\hline EDUCATION & .030 & $.009^{\mathrm{b}}$ & $.012^{\mathrm{b}}$ & EDUCATION & .035 & $.013^{\mathrm{b}}$ & $.023^{b}$ \\
\hline PROFESSION & .009 & $-.004^{b}$ & $-.004^{b}$ & EDUCATION & .011 & $-.006^{b}$ & $-.015^{\mathrm{b}}$ \\
\hline POSITION & .049 & $.036^{\mathrm{b}}$ & $.037^{\mathrm{b}}$ & POSITION & .043 & $.025^{\mathrm{b}}$ & $.015^{\mathrm{b}}$ \\
\hline $\begin{array}{l}\text { Your proficiency } \\
\text { in computer or } \\
\text { mobile phone use }\end{array}$ & .047 & $.048^{\mathrm{b}}$ & $.049^{\mathrm{b}}$ & $\begin{array}{l}\text { Your proficiency } \\
\text { in computer or } \\
\text { mobile phone use }\end{array}$ & .057 & $.054^{\mathrm{b}}$ & $.055^{\mathrm{b}}$ \\
\hline \multicolumn{8}{|c|}{ Independent variable } \\
\hline \multirow[t]{3}{*}{$\overline{\mathrm{DMC}}$} & \multirow[t]{3}{*}{.577} & \multirow[t]{3}{*}{.576} & \multirow[t]{3}{*}{.802} & DMC1 & .134 & .129 & .494 \\
\hline & & & & DMC2 & .151 & .155 & .420 \\
\hline & & & & DMC3 & .296 & .295 & -.073 \\
\hline \multicolumn{8}{|c|}{ Moderating variable } \\
\hline BT & & .077 & .293 & $\mathrm{BT}$ & & .071 & 0.333 \\
\hline \multicolumn{8}{|c|}{ Interactive item } \\
\hline \multirow[t]{3}{*}{$\mathrm{DMC} \times \mathrm{BT}$} & & & \multirow[t]{3}{*}{-.054} & $\mathrm{DMC} 1 \times \mathrm{BT}$ & & & -.089 \\
\hline & & & & $\mathrm{DMC} 2 \times \mathrm{BT}$ & & & -.063 \\
\hline & & & & $\mathrm{DMC} 3 \times \mathrm{BT}$ & & & .090 \\
\hline $\mathrm{R}$ & $.656^{\mathrm{a}}$ & $.667^{b}$ & $.668^{b}$ & $\mathrm{R}$ & $.666^{\mathrm{a}}$ & $.676^{\mathrm{b}}$ & $.682^{b}$ \\
\hline $\mathrm{R}^{2}$ & .431 & .445 & .446 & $\mathrm{R}^{2}$ & .443 & .457 & .466 \\
\hline$\overline{\Delta \mathrm{R}^{2}}$ & .431 & .014 & .015 & $\Delta \mathrm{R}^{2}$ & .443 & .014 & .013 \\
\hline $\mathrm{F}$ & 112.265 & 29.129 & 25.988 & $\mathrm{~F}$ & 58.644 & 24.296 & 19.173 \\
\hline$\overline{\Delta F}$ & 112.265 & 1.238 & 1.282 & $\overline{\Delta F}$ & 58.644 & 1.221 & 1.163 \\
\hline
\end{tabular}

It can be seen from Tab. 6 that after the BT moderating variables are added, the coefficient of the independent variable DMC is significantly reduced (from 0.577 to -0.054 ) and the $\mathrm{F}$ value of the model is also significant at the level of $\mathrm{P}<0.05$, which proves $\mathrm{BT}$ plays a mediating role between DMC and DPCI.

Therefore, our hypothesis $\mathrm{H} 2$ has been verified.

The regression coefficients of the interaction terms between the three factors of DMC and BT are significant. BT respectively positively regulates the influence of the three factors of DMC on DPCI. After the regression of the three-dimensional interaction items of DMC were added, the coefficients of the three factors of marketing power were significantly reduced $(0.134,0.151,0.296$ to $-0.089,-0.063,0.090)$, and $\mathrm{R} 2$ increased from 0.431 before the interaction to 0.013 , thus indicating that the interaction of the three factors of DMC and DPCI promotes corporate performance behavior.

This proves that the hypotheses $\mathrm{H} 2, \mathrm{H} 2 \mathrm{a} ; \mathrm{H} 2 \mathrm{~b}, \mathrm{H} 3 \mathrm{c}$ are all verified. 


\section{Correlation analysis}

Table 7 - Correlation analysis

(made by the author)

\begin{tabular}{|l|l|c|c|c|c|}
\hline \multicolumn{2}{|c|}{} & DMC1 & DMC2 & DMC3 & DPCI \\
\hline \multirow{2}{*}{ DMC1 } & Pearson Correlation & 1 & $.716^{* * *}$ & $.590^{* * *}$ & $.539^{* *}$ \\
\cline { 2 - 6 } & Significance (bilateral) & & .000 & .000 & .000 \\
\hline \multirow{2}{*}{ DMC2 } & Pearson Correlation & $.716^{* * *}$ & 1 & $.591^{* * *}$ & $.548^{* *}$ \\
\cline { 2 - 6 } & Significance (bilateral) & .000 & & .000 & .000 \\
\hline \multirow{2}{*}{ DMC3 } & Pearson Correlation & $.590^{* * *}$ & $.591^{* *}$ & 1 & $.608^{* * *}$ \\
\cline { 2 - 6 } & Significance (bilateral) & .000 & .000 & & .000 \\
\hline \multirow{2}{*}{ DPCI } & Pearson Correlation & $.539^{* *}$ & $.548^{* * *}$ & $.608^{* * *}$ & 1 \\
\cline { 2 - 6 } & Significance (bilateral) & .000 & .000 & .000 & \\
\hline
\end{tabular}

**. Significantly correlated at the .01 level (two-sided)

The results presented in Tab. 7 confirm that the correlation between DMC1 and DPCI is 0.539, DMC2 and DPCI - 0.548, and between DMC 3 and DPCI it is 0.608. The results also show that there is no problem of collinearity here.

Table 8 - Summary of the relationship model between DMC and DPCI

(made by the author)

\begin{tabular}{|l|l|c|}
\hline H1 & DMC is positively correlated with DPCI & Result \\
\hline H1a & $\begin{array}{l}\text { Creating and managing lasting customer relationships is positively correlated with } \\
\text { DPCI }\end{array}$ & Confirmed \\
\hline H1b & Predicted changes in customer preferences are positively correlated with DPCI & Confirmed \\
\hline H1c & $\begin{array}{l}\text { The ability to use digital marketing to meet customer needs to achieve customer } \\
\text { retention is positively correlated with DPCI. }\end{array}$ & Confirmed \\
\hline H2 & BT has a positive regulatory effect on DMC and DPCI & Confirmed \\
\hline H2a & BT security has a positive regulatory effect on DMC and DPCI & Confirmed \\
\hline H2b & BT trust has a positive regulatory effect on DMC and DPCI & Confirmed \\
\hline H2c & BT environmental supervision has a positive regulatory effect on DMC and DPCI & Confirmed \\
\hline
\end{tabular}

According to the above test, the relationship model between DMC and DPCI is as follows

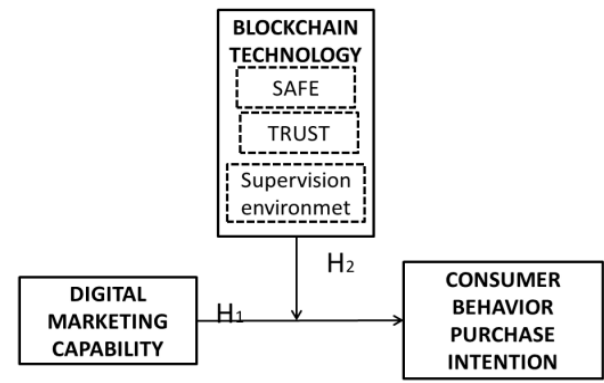

Figure 2 - Final model of the relationship between the variables in question (made by the author) 


\section{RELATIONSHIP BETWEEN DIGITAL MARKETING}

\section{Conclusions and recommendations}

Factors hindering digitalization include lack of digital maturity and functionality (Day, 2011; Kane et al., 2015), unclear digital performance gains (Leeflang et al., 2014), and the need to transform organizational functions and international business (IB) to support the digitization process. These challenges require the expansion of digital marketing functions and performance. D. Herhausen (2020) defines DMC as continuous dynamic interaction between interdependent trusted parties that enables any participant to take advantage of its value. This article puts forward the following suggestions:

a) DMC mainly comes from the resources invested in establishing relationships between enterprises and customers;

b) DMC strengthens company's internal operating system and integrates with BT to enhance core competitiveness.

\section{Research limitations and future research directions}

1. Research sample aspect. The survey in this study has covered business owners or supervisors of some small and medium digital platforms in Jiangsu, Zhejiang, Shanghai, Guangxi, Beijing, Shandong, and several other places. Although most of the research models

and research hypotheses constructed are supported and verified by the sample data, the research results and conclusions cannot be treated as universally applicable still and thus need further verification.

2. The research aspect. This research has been organized during the pandemic times, thus, questionnaire collection has been mainly online, and the collection channel is relatively simple. Also, the research objects selection process has been affected by many factors. Some of these factors cannot be fully explained operating the variables selected for this article specifically.

In the context of the digital age, the research on digital platforms is becoming one of the main research fields of the future "digital economy+". Future research also needs to dig deeper into technological innovations, BT, big data statistics, and platform systems. The research ideas can be expanded by putting forward constructive and operable suggestions as well as countermeasures based on the suggestions.

\section{References}

Antonopoulos, A. (2017). Mastering Bitcoin: Programming the Open Blockchain. O'Reilly Media.

Clohessy, T., Acton, T. \& Rogers, N. (2019). Blockchain adoption: technological, organisational and environmental considerations, in: Business Transformation Through Blockchain, 1.

Day, G.S. (2011). Closing the marketing capabilities gap. Journal of Marketing, 75,4, 183-195.

de Oliveira, R. T. (2017). Institutions, Middleman, and Blockchains - Shuffle and Re-Start. Supply Chain Management, January.

Diffie, W. \& Hellman, M.E. (1976). Cryptanalysis of the NBS data encryption standard. Computer. May.

Drescher, D. (2017). Blockchain Basics A Non-Technical Introduction in 25 Steps. Apress.

Dwyer, F.R. (1987). Developing Buyer-Seller Relationships. Journal of Marketing, 51,2, 11-27. 
Evans, P.C. \& Gawer, A. (2016). The Rise of the Platform Enterprise: A Global Survey. New York. The Center for Global Enterprise.

Fatima, W. (2020). Digital Marketing Capabilities in International Firms: A Relational Perspective. International Marketing Review, 37,3, 559-577.

Grönroos, C. (1994). From Marketing Mix to Relationship Marketing: Towards a Paradigm Shift in Marketing. Management Decision, 32, 2, 4-20.

Gwin, J.M. (1990). Constituent Analysis: A Paradigm for Marketing Effectiveness in the Not-for-profit Organisation. European Journal of Marketing. MCB UP Ltd.

Herhausen, D. et al. (2020).The digital marketing capabilities gap. Industrial Marketing Management, 90, 3, 276-290.

Herhausen, D., Mioevi, D., Morgan, R.E., D., \& Kleijnen, M. (2020). The Digital Marketing Capabilities Gap. Available online at: https://research.vu.nl/files/127957462/The_digital_marketing_capabilities_gap.pdf.

Kane, G.C., Palmer, D., Phillips, A.N. \& Kiron, D. (2015). Is your business ready for a digital future? MIT Sloan Management Review, 56, 4, 37.

Leeflang, P.S., Verhoef P.C., Dahlstrom, P. \& Freundt,T. (2014). Challenges and solutions for marketing in a digital era, European Management Journal, Vol. 32 No. 1: 1-12.

Mathews, S., Bianchi, C., Perks, K. J., Healy, M., \& Wickramasekera, R. (2016). Internet Marketing Capabilities and International Market Growth. International Business Review, 25, 4, 820-830.

Nakamoto, S. (2008). Bitcoin: a peer-to-peer electronic cash system. Available online at: https://bitcoin.org/bitcoin.pdf.

Penrose, E. T. (1959). The Theory of the Growth of the Firm. New York: John Wiley.

Rowley, T. J. (1997). Moving beyond dyadic ties: A network theory of stakeholder influences. Academy of Management Review, 22, 4, 887-910.

Saberian, F. \& Amirshahi, M. (2020). Linking digital platforms' service dimensions to customers' purchase. The Bottom Line Managing Library Finances, 33, 4, 315-335.

Svendsen, A. (1998). The Stakeholder Strategy: Profiting from Collaborative Business Relationships. Berrett-Koehler Publishers.

Taiminen, H. \& Karjaluoto, H. (2015). Industrial Branding in the Digital Age. Journal of Business \& Industrial Marketing, 30, 6, 733-741.

Teece, D. \& Feiler, P. (2014). Case study, dynamic capabilities and upstream strategy: Supermajor EXP. Energy Strategy Reviews, 3 (September), 14-20.

Treiblmaier, H. (2019). Toward more rigorous blockchain research: recommendations for writing blockchain case studies. Available online at: https://www.frontiersin.org/articles/10.3389/fbloc.2019.00003/full.

Paper submitted

Paper accepted for publishing

Paper published online
12 August 2021

20 October 2021

30 November 2021 